Yatsenko T. S.

Doctor of psychological Sciences, Professor, Academician of the National Academy of Pedagogical Sciences of Ukraine, Head of the Department of Psychology, Deep Correction and Rehabilitation yacenkots@gmail.com

Amurova Ya. V.

Post-graduate student of the Department of Psychology, Deep Correction and Rehabilitation,amurova23@gmail.com Bila O.A.

Post-graduate student of the Department of Psychology, Deep Correction and Rehabilitation lenokbila@ukr.net

\title{
THE PHENOMENON OF GUILT AND ITS ARCHAISTIC ESSENCE
}

Summary. The basis of the research is the psychodynamic theory and the corresponding practice of deep knowledge of the psyche in its integrity (conscious / unconscious). The article focuses on the methodological and instrumental aspects of knowledge of the phenomenon of guilt in the depth-correction process using visualized means, based on archetypal symbols. The interconnection of guilty with a tendency to self-guilty and the Oedipus complex, which has archaic origin, is stated. The content of the article characterizes the guilt and feeling of guilt of the subject in relation to the conscious and unconscious aspect of the psyche.

The article deals with the phenomenon of guilt in relation to original sin and Christian faith. After all, sin causes a feeling of guilt, which is expressed individually uniquely. In Christianity, sin and guilt are united by their archaic nature, but man is conscious of sin, and guilt is predominantly unconscious. Therefore, the significance 
of original sin as one of the factors of guilt, in connection with the effectiveness of the substructure of the psyche - Super-Ego is revealed.

For the first time it was stated that the archaic origin of the fault can be investigated theoretically, in the practical aspect archaism of guilt is not autonomous, separated from the individualized psyche of the subject. It is stressed that the archaism of guilt cannot detect itself directly in the mind of the subject, which determines the use in the in-depth knowledge of mediated means.

The energy potential, which carries a sense of guilt, and negatively affects the psyche of the subject is analyzed. Therefore, the fault in the deep-correction process is known in unity with the archetype. Echoes of the guilty's archaism are reflected in the individualized psyche of the subject and are objectified through drawings of guilt, author's drawings, etc.

Key words: archaism of guilt, archetype, Superego, active social and psychological perception, Oedipus complex, original sin

\section{Яценко Тамара Семенівна}

доктор психологічних наук, професор, академік Національної академії педагогічних наук Украӥни, завідувачка кафедрою психології, глибинної корекції та реабілітації Черкаського наиіонального університету імені Богдана Хмельнииького М. Черкаси (Украӥна) ORCID 0000-0002-1996-66IX yacenkots@gmail.com

\section{Амурова Яна Володимирівна}

аспірантка кафедри психології, глибинної корекції та реабілітації

Черкаського національного університету імені Богдана Хмельниџького

М. Черкаси (Україна)

ORCID 0000-0002-3486-1138 


\section{Біла Олена Анатолї̈вна}

аспірантка кафедри психології, глибинної корекції та реабілітації

Черкаського нащіонального університету імені Богдана Хмельнищького

М. Черкаси (Украӥна)

ORCID 0000-0003-1326-3400

\section{ФЕНОМЕН ВИНИ ТА ЙОГО АРХАЇЧНА СУТНІСТЬ}

Анотація. В основу дослідження покладено психодинамічну теорію та відповідну практику глибинного пізнання психіки в іiі цілісності (свідоме / несвідоме). Стаття зосереджує увагу на методологічному та інструментальному аспектах пізнання феномену вини у глибинно-корекційному процесі з використанням візуалізованих засобів, із опорою на архетипну символіку. Констатовано взаємозв'язок вини із тенденцією до самопокарання та Едіповим комплексом, що мають архаїчне походження. Зміст статті характеризує вину та почуття вини суб'єкта у співвідношенні із свідомим та несвідомим аспектом психіки.

У статті розглянуто феномен вини у взаємозв'язку з первородним гріхом i християнською вірою. Адже гріх спричинює почуття вини, яке виражається індивідуально неповторно. У християнстві гріх і вина об'єднані їхньою архаїчністю, однак гріх людина усвідомлює, а вина переважно $\epsilon$ неусвідомленою. Тому розкривається значення первородного гріха, як одного 3 чинників вини, у взаємозв'язку з дієвістю підструктури психіки - Супер-Его.

Вперше вказано, що архаїчне походження вини можна дослідити теоретично, у практичному аспекті архаїзм вини не буває автономним, відокремленим від індивідуалізованої психіки суб'єкта. Наголошено, що архаїзм вини не може виявляти себе прямолінійно у свідомості суб'єкта, що й зумовлює використання в глибинному пізнанні опосередкованих засобів.

Проаналізовано енергетичний потенціал, який несе почуття вини, i негативно впливає на психіку суб'єкта. Тому вина у глибинно-корекційному 
процесі пізнається в єдності 3 архетипом. Відголоски архаїзму вини відображаються в індивідуалізованій психіці суб'єкта і об’єктивуються через малюнки вини, авторські малюнки тощо.

Ключові слова: архаїзм вини, архетип, Супер-Его, активне соціальнопсихологічне пізнання, комплекс Едіпа, первородний гріх.

The definition and relevance of the problem. The archaism of guilt originated from the primitive society and has been referred to the original sin and the psyche of every person. The energy potential of the feeling of guilt has negative affect onaperson's psyche.

Archaism of guilt in its synthesis with deep psychological determinants, which causes the influence on a person's psyche, has not been studied enough. The research is carried out in the context of the psychodynamic theory, which takes into account the integrity and unity of the psyche in its conscious and unconscious manifestations.

Hypothetical assumption:guiltis of an archaic origin, it influences the tendency development towards self-punishmentcaused by the Oedipal complex.

Methods. The article is based on the method of active social-psychological perception (hereinafter - ASPP), developed by T. Yatsenko [22-26]. The diagnosticcorrectional procedure of ASPPprovides the use of the subjectified means of deepperception (thematic psychological tattoo, reproductions of artistic works, work with subjectified models of stones, etc.). The leading mechanisms of the ASPP organization are the positive disintegration of the psyche as well as its the secondary integration at a higher level of development [23].

The purpose of the article is to analyzethe psychological phenomenon of guilt and its archaic influences onthe psyche activity semantic parameters.

Presenting of the main material. Analysis of scientific sources showed that the phenomenon of guilt was investigated by foreign scholars, namely by S. Grof, M. Klein, S. Freud, E. Fromm, K. Horney, C. Jung as well asnational ones: 
O. Matlasevych, O. Tsarkova, T Yatsenko, etc. In the scientific literature, guilt is represented as a moral-legal category and as a psychological concept as well. For the deep perceptionof the psyche, it is important to study the archaism of guilt as an archaic heritage of mankind.

In the foreignwords dictionaries, the term "archaism" is defined as a concept that has an ancient origin and remains. "Arche" means the beginning, primitiveness, the basis of everything. Most dictionaries define archaism as an outdated word ora phraseologism $[1,12]$. The psychoanalytic literature analysis makes it possible to distinguish the psychological meaning of the notion of "archaism".

The dictionary of analytical psychology defines archaism as the ancient nature of the psyche and the traces of primitive existence, which are reflected in a person's psychic life.

The image is considered archaic, if it has a mythological, historical and cultural significance, for instance, Oedipus myth [5]. The dictionary of "Psychoanalytical terms and concepts" describes "the archaic states of the Ego" as a reflection of feelings and experiences in the psyche of a mature that are characteristic features of the early stages of the Ego development. According to Freud, the Ego archaic states can be caused by the lack of separation of the child from the parents. For example, a child who did not have autonomy would try to find a substitution of primary libidinal objects by joining religious communities [9]. The archaic origin of guilt can be investigated theoretically, while the practical aspect of the archaism of guilt is not autonomous and is separated from the individualized person's psyche.

T. Yatsenko writes on the relationship between the archetype and archaisms: "Psychological realities synthesize transpersonal and archaic preconditions which come from the depths of the psyche and are transmitted and objectified in archetypal way" [24, p. 342]. Archaisms, as well as archetypes, are characterized by symbolism, which makes possible the phenomenon of guilt to be manifested through archetypal symbols. The concept of "archetype" (from the Greek arce - the beginning and typos - form, pattern) is still found in the works of the late antique philosophy scholars (Philo of Alexandria and others), and is considered by them as an idea and a 
prototype $[13,14]$. In psychological literature, S. Freud was the first who introduced the notion of archetype exploring the symbolism of dreams. The founder of the analytic psychology, C. Jung considered archetypes as inherited psychic structures, primary schemes, the most ancient, universal and eternal images that are natural for every person [21]. Guilt in the deep correctional process is experienced in conjunction with archetype. Some features of guilt are being reflected in a person's individualized psyche and are objectified through illustrations of guilt, author's drawings, etc.

Guilt can be considered both as conscious and unconscious. The conscious guilt is expressed in the feeling of guilt, and the unconscious guilt is stipulated by archaisms of the Oedipean origin and has a hidden but active influence on a person's life and needs to be experienced completely.

Consequently, the notion of "guilt" (which has archaic roots) and "feeling of guilt" are not identical.

A feeling of guilt is characterized as a state that occurs after committing a deed that contradicts social norms. The unconscious motives instigate a person's selfpunishment, determine the criminal behavior, etc. [6]. Aggression against other people contributes to a person's fantasies of punishment, fear of retaliation, etc.

As a result, feeling of guilt is associated with fear of punishment, anxiety and reproach of conscience. In order to reduce the level of tension from awaiting the punishment from the outside, a person commits self-punishment. The aggression caused by guilt is directed against a person in an expectation of forgiving through humility and atonement. A person's destructive reaction can be simultaneously a feeling of guilt component as well as a way to cope with it [9].

A person apprehends his guilt before the authority for not fulfilling his demands. On the unconscious level a person feels guilty even for not justifying his own expectations [19]. In other words, a person feels guilty through reproaches of conscience. The conscious guilt is caused by action, deed, misconduct that contradicts moral rules. However, a person is not able to identify the underlying factors that cause unconscious guilt, therefore, it is important to participate in the 
deep correctional psyche experience. The latter allows a person to identify the unconscious sources of guilt that actualizes the self-punishment tendency.

According to T. Yatsenko, "there are grounds to believe that the archaism of guilt (its unconsciousness), constantly sets the self-punishment tendency" [24, p. 341]. The unconscious guilt motivates a person to self-identification with the Jesus Christ long-suffering image. The unconscious of guilt may in some way influence a person's sense of self and behavior.

Repression is one of the protective mechanisms of the psyche. As a result, uncomfortable feelings, thoughts, attraction and experiences are repressed from consciousness into the unconscious sphere. The repressed desires, memories, experiences and feelings cannot be returned to the conscious sphere by the "Ego""s will, they disappear, preserving the energy potential and continuing their own existence in the feeling of guilt [4]. For this reason, the unconscious guilt is expressed in various forms of self-punishment.

Among the mechanisms that cover the feeling of guilt, these two tendencies are considered to be predominant: 1) inactivity, severe non-aggressiveness, refusal of competition (as well as from oneself), etc.; 2) imputing of one's own guilt to other people, accusation of a person's guilty actions [8]. The point we wish to stress here is that the unconscious guilt defines the tendency of the guilt transferring (projection) to another person, as well as the introjection of another important person's guilt [24]. In the Dictionary of Practical Psychologist (based on the ideas of S. Freud), guilt is adapted as follows: 1) guilt as a precondition is a specific feeling, based on the Oedipus complex and serves as the motive for committing criminal acts.

In order to realize the internal guilt feeling, a person is forced to seek punishment in order to alleviate his state. "The feeling of guilt is not the result of a misdemeanor, but, conversely, misconduct has been stipulated by this feeling. This feeling is not a consequence but a motive of a crime!" [4, p. 530]; 2) the unconscious guilt is of an archaic origin and consists in the perception of the unconscious, incomprehensible "guilty" feeling, which can interfere with psychological correction; 3) moral guilt arises from the contradictions between the Ego and the Superego [the above-noted 
work]. Guilt is also determined as the driving and motivating force of selfpunishment, and therefore is associated with masochism. Guilt, therefore, reflects the state that arises as a result of the internal conflict between the Ego and the Superego as Oedipus complex [6,20]. The unconscious guilt is inherent to a person, consequently, it can express itself through mediated forms that cover it [24].

The unconscious guilt while integrating into the psyche, acquires individual features, covering it as a tendency to self-punishment (self-destruction).

Guilt can be expressed through the feeling of shame. Shame is a person's feeling that arises from self-criticism (self-blame) or humiliation by other people, the condemnation of person's thoughts and actions that contradict moral rules, etc.

The felling of shame originally occurs under the influence of people's presence. Later, being introjected by the person's psyche, it enters into the sphere of Superego (conscience). A person can feel shame even in isolation, without being blamed.

Accordingly, the feeling of shame is stipulated by the values and ideals, inherent not only to the individual, but also to culture in general $[3,9]$.

The Dictionary of Practical Psychologist [4] defines fear as the guilt cause, which can be transformed into conscience afterwards. Fear is expressed in two forms, which are considered to be the cause of guilt: 1) the authority fear involves refusal to meet the primary needs; 2) the unconscious fear imposed by the Superego makes a person abandon of forbidden desires and stipulates self-punishment.

According to E. Fromm, the feeling of guilt arises from the conscious influence, which is formed under the influence of society. He made a distinction between the authoritarian and humanistic conscience. The authoritarian conscience arises from external authority (parents, power, and religion) and causes a sense of security, since it provides closeness to authority and its approval. The authoritarian conscience is guided by destructiveness and focused on personal Ego. The humanistic conscience is a person's reaction to his own psychic life. It is also productively oriented and reflects the Ego's moral experience. The authoritarian and humanistic conscience do not exist separately, they are interrelated [19]. 
The study of the archaism of guilt resulted in the need of philosophical and psychological literature analysis. An overview of scientific sources was based on the principles of psychodynamic theory and it emphasizes the importance of the unconscious guilt for the psyche self-organization.

The conscious guilt is a violation of moral and legal standards in a person's thoughts or actions. The conscious guilt has been affected the society. The unconscious guilt is caused by the deep factors of archaic origin that have been repressed. The unconscious guilt is detected only by mediators and may cause the determination of destructive effects. The latter manifests itself in the tendencies towards psychological death, the psychic impotence, aggression, self-punishment, self-deprivation, masochism, etc. While reviewing the literature two factors of guilt have been discovered: the original sin - patricide and guilt, which is determined by the Oedipus complex ("Incest taboo ").

The representative of the depth psychology C. Jung made a distinction between the collective and personal guilt. The scientist posited that the personal, individualized guilt is always influenced by archaic and archetypal factors [5]. The collective guilt is associated with the original sin inherent to all people.

We will consider two theories of the original sin origin: religious (Christian) and psychological (patricide in the primitive society).

Archaism of guilt is being represented in the Christianity. It has declared itself a religion of the oppressed, who expect to be free from the unbearable life and work conditions after the coming of the Messiah - Jesus Christ. With the spread of the Christianity, the notion of sin as a violation of the moral rules of the divine command entered the European society. The original sin occurrence has affected the formation of morality in the Middle Ages and further [13]. In the Christianity the phenomenon of guilt is connected with sin. As a matter of fact, sin causes a feeling of guilt, which is expressed uniquely. In the Christianity, sin and guilt are united by their archaic nature. But sin is realized by a person, while guilt is mostly unconscious.

According to religious beliefs, sin is a transgression of God's will, embodied in moral norms, and religiously sanctioned requirements with regard to a person's behavior 
and way of life. The Christianity explains the occurrence of $\sin$ by the myth of the original sin. The first people Adam and Eve violated the commandments of God, having tasted the apple from the tree of knowledge of good and evil [13].

Then God drove out Adam and Eve from the Garden of Eden and since their sin has begun to be inherited by the next generations. Consequently, a person has no choice of being sinful or not. A person is born already with the ancestors' sin.

S. Freud studied the nature of archaic fault and came to the conclusion that modern Christianity is inseparable from it. Christ died in order to free humankind from original $\sin$. Indeed “... this sin had to be death or murder. Life as a sacrifice could be demanded only in return of murder" [16, c. 348]. Perhaps, people are still suffering guilt over the crucifixion of Jesus Christ, who was the spiritual leader, the Son of God. The above explains the attraction of humanity to the Christianity.

Religion actually provides protection to believers, a chance for redemption and feeling guilt weakening. The psychological defenses conceal the true causes of the individual guilt, giving rise to illusory beliefs about universal pardon of sins.

Study of the archaism of guilt has allowed us to clarify the category of original sin.

A lot of events described in the Bible (the Old Testament) are considered to be immoral, and moreover, some actually point to incest. Although, these events escape conviction, since they have take place under the patronage of God.

The fragment from the Bible: "And he said to them, Thus said the Lord God of Israel, Put every man his sword by his side, go on and out from gate to gate throughout the camp, and slay every man his brother, and every man his companion and every man his neighbor "(Ex. 32:27). Later, God prohibited such actions: "None of you shallapproach to any that is near of kin to him, to uncover there nakedness: I am the Lord! "(Leviticus 18: 6). Even the great prophet Moses was born in the result of an incest:" And Amram took him Jochebed his father's sister to wife; and she bore Aaron and Moses "(Exodus 6:20).

Intestdescribed in the Bible [2], is not condemned, but on the contrary taken for granted. Then what is the sin of man? Disobedience, confrontation with God, conflict, the desire to become equal to God are considered to be characterized as $\sin$. 
Therefore, God drove out Adam and Eve from Paradise, because they disobeyed, became God-like, knowing good and evil.

Among the many "sinful" events that are described in the Bible [2] are the following. One man is married to two sisters at the same time (Gen. 29: 2-30), two daughters have sexual relations with their father (Gen. 19: 32-36), brothers sell their brother (Gen. 37: 26-27), father-in-law has a sensual contact with his daughter-in-law (Genesis 38: 15-18). These statements point to the meaningofincestdesires not only for the reason of their prohibitions, but also because of their violation.

Thus, we may conclude, thatguilt common to all mankind is characterized by archaism, which has an impact on an individualized guilt feeling.

The psychological theory of the origin of original sin is based on the following statement: if the original sin meant to be guilty before God the Father, the most ancient crime of mankind was patricide, the killing of the forefather of primitive society. Consequently, the father's image remained in memory and later became a divinity, weakening the feeling of guilt [16, p. 347-348].

The aforesaidcan explain the totemism development, which recognized the relationship betweenageneration ora tribe and a certain animal or plant.In totemism, taboo protected the life of a totemanimal. The notion of "totem" means"his generation or "his family". A legendary ancestor and patron of the family, ethnic group or a tribe were considered to be a totem [8]. S. Freud regarded this as the first attempt to create a religion. The totem animal was perceived as the closest and natural substitution of the father, before which the sons expressed more than just their penance. Father's substitution allowed opening the prospect of feeling of guilt calm through reconciliation. Totemism was the substitution of an "agreement with the father" and gave his sons all that the children might desire: care, protection and leniency, which seemed to be compensation.

Instead, the sons were obliged to take care of their totem-father that provided not to commit the act that had led to the true father murder.

The latter is reflected in the Ukrainian proverb that says "It's easier to beat a farther together". Thus, totemism contributed to a different interpretation of historical 
circumstances and stipulated a repression (loss of memory) of the act of patricide (which it originated from) [18].

This phylogenetic hypothesis shows that civilization is still being captured by archaisms.

The memory of prehistoric events and deeds acts lives in society. The repressed is recurring, "... a person is still punished for the humiliated desires and uncommitted acts' [7, p. 58]. Consequently, a person feels the unconscious guilt over events which he was not actually involved. Therefore, a person is seeking for safety and calming down in religion due to feelings of guilt reduction. For that reason, repentance is so widespread among people.

The feeling of guilt is actualized under the influence of the ambivalent feelings to parents.There is also the constant struggle between Eros (the instinct of life and love) and Tanatos (the instinct of death, destruction and aggression). The fundamental conflict (life - death) is constantly becoming acute when a person faces a problem - "to be or not to be". It has rise in the perinatal period and continues in the process of socialization and coexistence with society [17].

In psychodynamic theory, the notion of "oedipal perfection" is introduced. T. Yatsenko states: "The oedipal perfection corresponds to the postulate of a person's inevitability from "being guilty since the embryo" by reason of the intrauterine incest" [24, c. 341$]$. In other words, being in a mother's womb causes a bloody relationship to the taboo memeber of the family ("girl $\leftrightarrow$ father"; "boy $\leftrightarrow$ mother"), as well as to the genital organs during the birth.

A child demonstrates an interest in the intimate sphere of human life quite early. The firstchild's sexual desiresare directed towards the closest people (parents, brothers, sisters) [15]. Among these forbidden desires is the inclination to parents, which later are felt by a child through taboo. Consequently, it catalyzes the unconscious fault. In humanistic psychology guilt is connected with incest desires that are actualized in early childhood. E. Fromm noted: "The most effective way to weaken a child's will is to elevatehis feeling of guilt" $[19$, c. 165]. When a child reveals the first sexual impulses, adults restrain and restrict them blaming as much as 
possible. Thus, an associative connection between sexual desires and guilt is formed [the above-noted work]. Consequently, the facts proposed by E. Fromm have a remote effect and lead to the development of psychic self-impotence, psychological death and self-deprivation $[11,22]$.

As it has been already indicated, archaism of guilt cannot be manifested straightforwardly in a person's conscious and causes the use of mediated means in deep perception.

The spontaneous tattoo drawings by the ASPP participants (in particular, the tattoo of guilt) and the choice of the representatives (reproductions of paintings) have already embodied the effectiveness of the mankind archaic heritage, that is specified in the archetype of symbols related to the individualized psychic features.

The author of the ASPP method states: "The applicationof visualized material in our research opens the prospect of a figurative modernization of the archaic heritage presentation of the unconscious guilty trends that catalyzes their elucidation in the dialogic interaction” $\mathrm{P} \leftrightarrow \mathrm{R}$ “[24, p. 341]. Therefore, the dialogue allows investigating the phenomenon of guilt which is of archaic origin temporally (spatially).Accordingly, the study is based not only on a person's psychic reality visualization, but also on the archetype of symbolism and the disclosure of its semantic aspects in dialogic interaction "psychologist $\leftrightarrow$ respondent" ("P $\leftrightarrow R$ ). Thearchetype ability to recoding archaic sources of psychic reality into visual (modernized) forms which are ontologically adapted to a person'spsychic uniqueness is taken into account. The instinctive qualities of the archetype in its integrative indivisibility with a person's psyche make it possible.

Realizing the complexity of the problem, we tried to design an experiment so that the task performed by the ASPP participants was close to the archaic psychic aspects. It gave a rise to the idea of performing a "Tattoo" psychological drawing in assotiation with the synthesis of phylogenesis and ontogenesis. In the purpose of the cognition objectiveness, a person is given a task to draw two tattoos concerning "Personal tattoo" and "Tattoo of Guilt". A psychologist even puts a chair on which 
Guilt seems to be sitting (the task is to draw its tattoo). As the practice has shown there were no identical thematic drawings.

The next task to be performed was to match the Tattoosto the reproductions of artistic works that would help to reveal their content. Everyone managed successfully. The third task was to putthe selected reproductions of paintings in significant order (to each Tattoo separately).

Following the above organizational preconditions, the stage of dialogic and analytical interaction between the psychologist and the respondent starts.It is focused on the Tattoo analysis chosen by the respondent.

The tasks given to the respondent must be specified: a) no particular form is required to perform psychological tattoos concerning "Personal tattoo" and "Tattoo of Guilt";b) to match the Tattoo drawingsto the reproductions of artistic works that are associated withtheir content; c) to putthe selected reproductions of paintings in order significant for the respondent; d) to determine the priority (primacy) of the "Tattoo" analysis.

Deepcorrectional process with respondent I.

I.: I drew two "Tattoo"drawings (ill. 1, ill. 2). I propose to start analysing the "Tattoo of Guilt".

P.: We see the drawing of "Tattoo of Guilt" (Ill. 1) and a glass bulb with "umbilical cords" inside as an archetypal symbol of the womb is depicted on it!
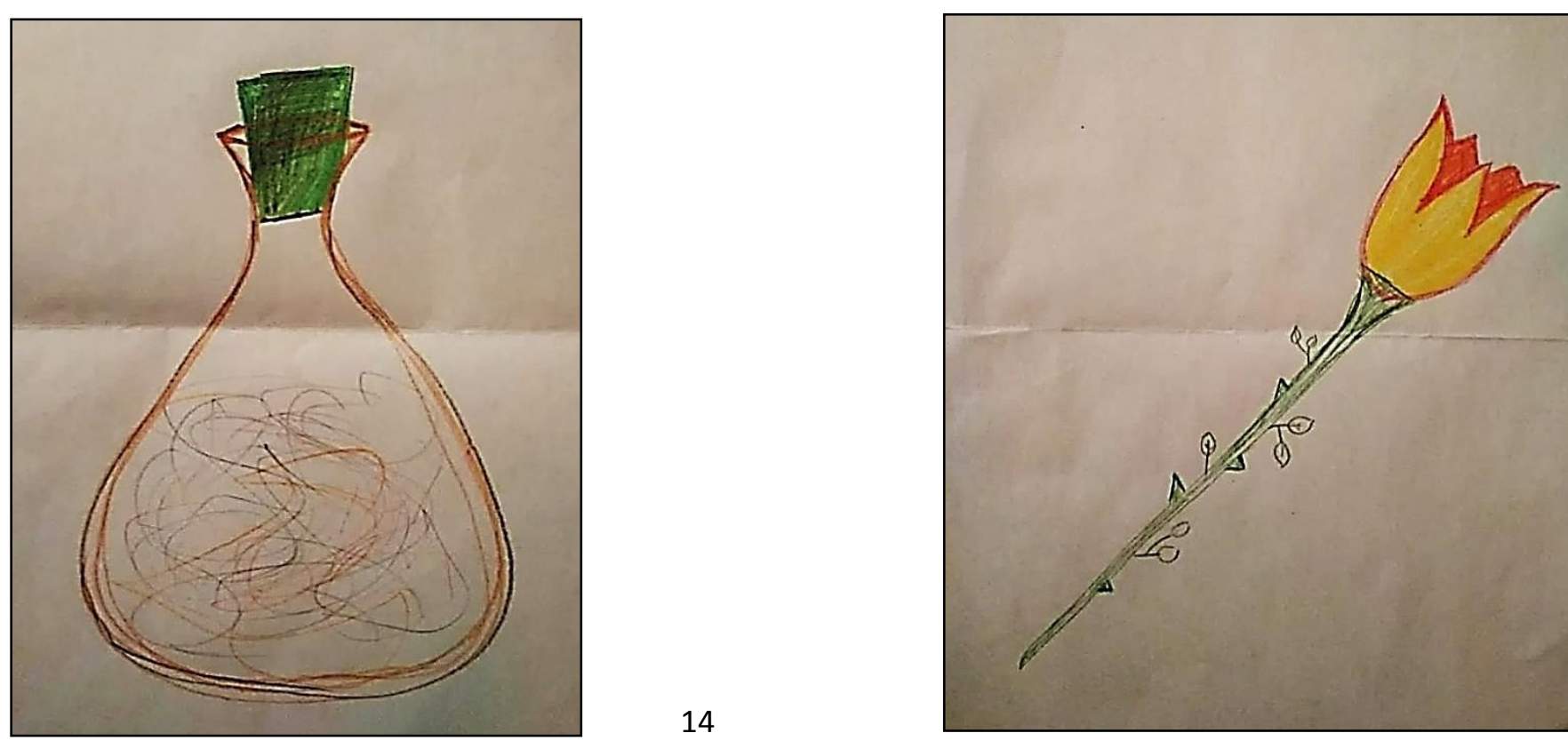
Ill. 1. "Tattoo of Guilt"drawing

Ill. 2. "Personal tattoo" drawing

I: I would like to start analysing from it. I matched the reproductions to the "Tattoo of Guilt" picture. I was very afraid to take this picture (ill. 3) but I did take it

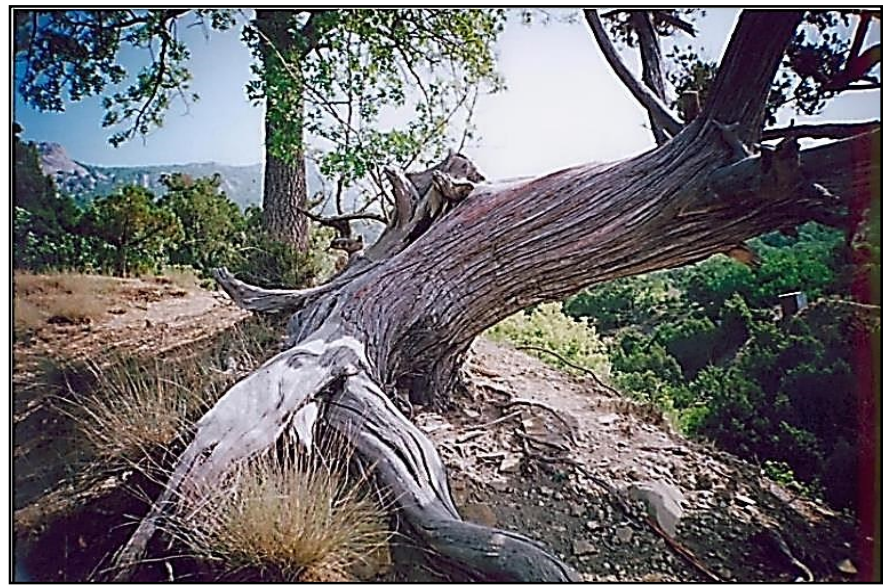

Ill. 3. Laspi Bay as essential.

P.: It's just the nature. What do you see?

I.: It's a shame ... Because the root of a tree is similar to a man's legs and his genital organs.

P.: Really. Although it's just the root of the tree. Obviously, your dependence on your father is manifested. As a result, shame can be catalyzed by "incesttaboo"!

Illustration 1 depicts a stopper that the bottle takes, as if there is neither entry nor exit. It's good that you have had a baby. The bottle itself (or a glass bulb) symbolizes the intrauterine state. And shame is associated with guilt. You are the first who has noticed a hint on male genital organs on this illustration (ill. 3). That is the power of archetypal symbols!

I.: This is nature (ill. 3), it's all natural but very shamefull.

P.: Thisisthe echoe of edipus dependence. And what would you say about “Tattoo of Guilt"drawing (ill. 1)?

I: It's like a closed bundle of energy. This energy is bad,something like offence, and that's why it's closed. I closed and hid it thoroughly. The bottle itself is large, and the entry (bottle neck) is small.

P.: Has it closed?Is there anything going out?

I: Yes, I feel this risk of uncontrolled tension breaking.

P.: What else can be put there except what you have said? 
I: When something is going wrong, I can feel tension (offence or guilt) - I block it and shrink into myself, but it's still inside me.

$\mathrm{P}$.: Are you afraid of your reactions? Are they not desirable for you, because the consequences can be bad or unpredictable for you and for other people?

I. Yes.

P.: So, mortido has been blocked. You got so much libidinal and constructive energy from your father in childhood.But then separation fromyour father turned into the energy of the mortido. As a result you feel sad, offended and disappointed.

I: I was looking for a proper partner, I did everything in order to choose the right husband, but I did not manage, obviously.

P.: You haven't got free from the ideal relations with your father.You don't differentiate them. But you are looking for the same feelings (calm, comfort, reliability, fascination, security, boundless confidence etc) as it was in childhood with your father*.

I: I have it all, but I do not show it, and it is squeezed like in that bottle.

P.: Yes, because you are protecting everything given by your father. Taking into accoont our previous meetings, we might conclude that it's your secret in order to keep the holy relationship with your father. You have been extrapolating guiltto your husband so far. You should understand that this is Sisyphean labour. The more libido energy there is, the less space for mortido there will be. As a result, you will blame your husband for being "not your father" to a lesser extent."

I.: So should I learn to give libido?

P.: Both give and feel. The following picture(ill. 4). What do we see on it?

I.: This is me and my guilt as a burden (a boat is full of everything like a bottle (ill. 1).

P.: That is, guilt is so great that the "dove"is not able to move it?

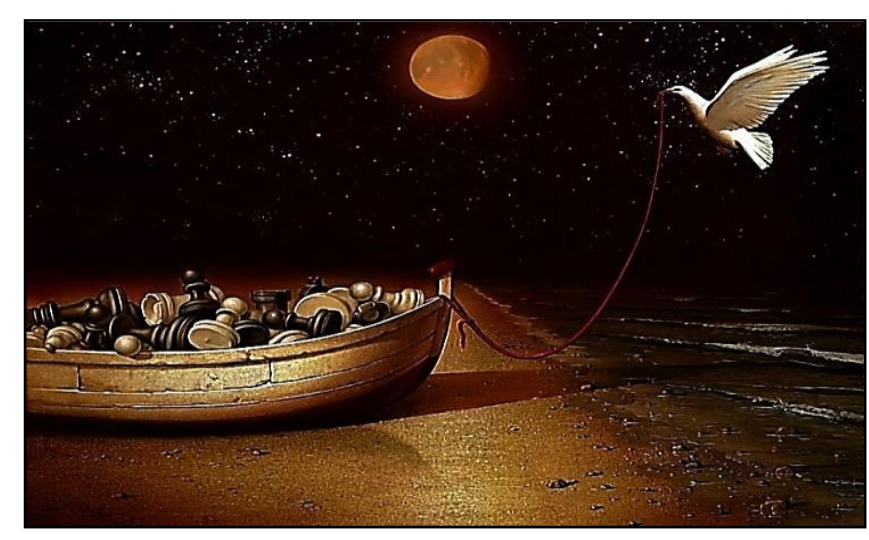

Ill.4. Zademack "Dove of Peace" 
I.: Yes, for me to move is just a desire.

P.: Does itsuppress you?

I: It seems to me there is light at the end of the tunnel, but...

P.: According to archetypes, a thread

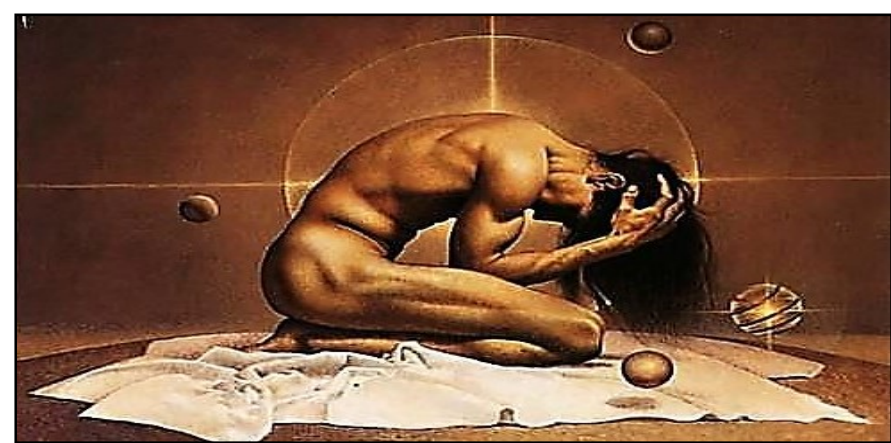
(or a lace in a dove's beak) symbolises an umbilical cord, and a boat is a womb, but being empty it is not fertile (ill. 4).

It means that your dependence and everything that happens to you is not lifeaffirming, but destroying. It's worth thinking.

\section{Ill. 5. J. J. Palencar}

Let's view the next picture (ill. 5). Is this your state or your husband's?

I: Probably his. I feel guilty because he is in that state, and I am concerned in. I cause this state.

P.: So, have you "brought him to bay" and then felt guilty? If a person feels guilty, he or she wants to get free of its feeling.

I.: Despite the fact that he (my husband) is (ill. 5) "offended", but at the same time he is complete and strong.

P.: Does he want you to symphathize with him?

I: Possibly, is a kind of a game.

P.: Now you have to change the ways of interaction with him and express more libidinal energy. Do not sit in the corners of different rooms both.

I.: I need a round apartment (laughs).

P.: The next picture shows a tendency to the womb returning (ill. 6). Are you under water like in the womb? Why did you choose this picture?

I.: Peace, silence and calm are depicted there. 
P.: Yes, silence and calm like in the womb.

But, obviously, it looks like a"grave", because theburden does not allow you to get out of there and breathe. The tendency "to psychological death" may be identified.

Ill.6. Picture by M. Mawson

"Under Water"

I: It concerns me, but what should I do? I feel hopeless at such a pursuance of peace. One can get tired of himself.

P.: In the following picture (ill. 7), we see, apparently, you and your husband. Are you in a dominant position?

I.: Yes, that's right. This is me (ill. 7, points to the figure from above), and this is he (ill. 7, figure below).

P.: Concequently, being in a dominant position, you join your father.

He was sitting over you when you were little and helpless (ill. 7).And now you are making your husband to be helpless, because he is not able to provide you with it.

A wise psychologist said: "It does not matter what your parents gave you, it's important what you will give to

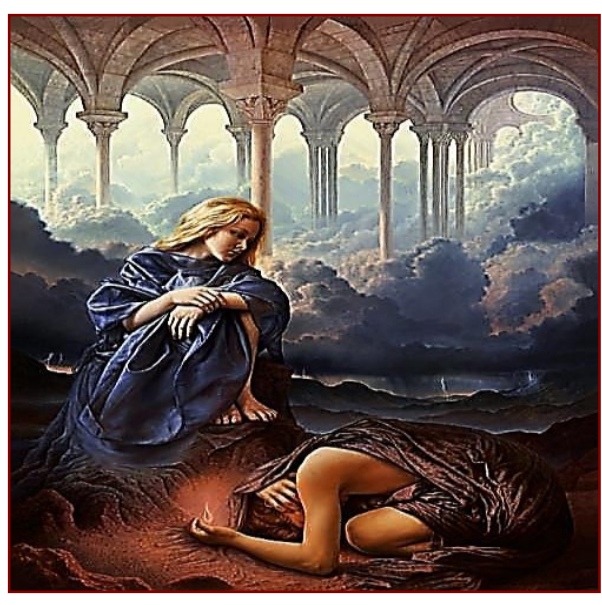
yourself." Remember that. Ill.7. Smorenburg "The Gift"

I: So, having chosen a picture with my father (ill 8, which I. matchedwith the "Personal Tattoo" drawing) I am trying to matchit with my husband at certain points. But the problem is that at first I make him to feel hopeless.Do I punish him for anything? Because he is "not my father" and that I do not have that period, or rather those feelings, as in ill. 8. I have to stop it and to create something new with my husband.

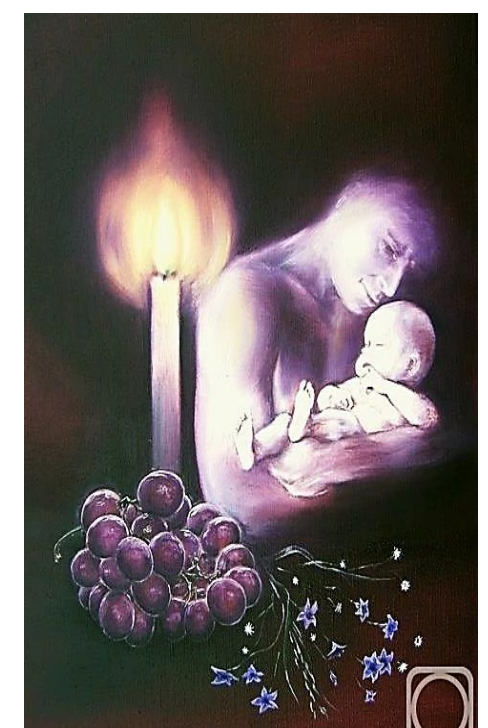


P.: You are right, you are making a progress. If your father loved you so much, you should love yourself much more. You must notcause harm to yourself by destructive feelings and tears.It destroys soul and damages both psyche and health.

You're young and beautiful, and you are making a progressin ASPP. I think that everything will be fine.

Ill. 8. Gasilov V. "Evening"

I. named it "My father and I"

I: Thank you for your work.I feel relief and strength to release from the burden of problems. Let's view the thepersonal Tattoo drawing tomorrow, I am in a hurry.

Summing up the empirical material of the deep correctional work, we may conclude that the guilt phenomenon relevance for the respondent I. is generated by emotional dependence on his father. Archetypaical symbols (thread, boat, bottle, a girl under water) objectifiyarchetypaicaly the tendency of womb returning, as well as self-punishment, that covers guilt. A person's unconscious guilt is projected or transferred to another person (a man who is guilty of not being like a father). This case is interesting because psyche is programmed not by a trauma, but, on the contrary, by libidinal fixation which I. paradoxically tries to reproduce. The respondent wants her husband to commit similar acts, which determines the grounds for his punishment, making him to be "helpless child" (see the similarities in ill. 7 and 8).This situation hintson archaism of guilt, because of its deepeningand falling outside the real content of I.'s happy marriage .

The archetypical symbols help to outline a person's problems in the diagnosticcorrectional process. The unconscious guilt actualizes the self-punishment tendency. The study reveals thefact that the oedipal factors influence the occurence and development of a person's feeling of guilt.The obtained results confirm the significance of the ASPP method in the study of deep factors of guilt in the Tattoo drawings.

The perspective of the researchconsist in the further deep analysis of the perinatal period role in the person's development for the feeling of guilt occurrence and its influence on the formation of mental dysfunctions. 


\section{References}

1. Bybyk S.P., Siuta G.M. (2006) Slovnyk inshomovnykh sliv: tlumachennia, slovotvorennia ta slovovzhyvannia. [Dictionary of foreign words: interpretation, wordformation and word-usage]. Kharkiv: Folio. (in Ukrainian)

2. Knyzhkovyi Klub "Klub Simejnogho Dozvillia" (2015) Bibliya. Knigi Svyaschennogo Pisaniya Vethogo i Novogo Zaveta[The Bible. Books of Sacred Scripture of the Old and New Testaments]. (in Russian)

3. Voitko V.I.(1982)Psychological Dictionary.[Psykholohichnyi slovnyk]. K.: "Vyshchashkola". (in Ukrainian)

4. Golovin S. Yu. (1998)Slovar prakticheskogo psihologa. [Dictionary of Practical Psychologist.]. Minsk: Harvest. (in Russian)

5. Zelensky V.V. (2008) Tolkovyiy slovar po analiticheskoy psihologii.[Explanatory Dictionary on Analytical Psychology]. Moscow: Kogito Center. (in Russian)

6. Laplanche J. (2010)Slovar po psihoanalizu.[Dictionary of psychoanalysis]. St. Petersburg : Center for Humanitarian Initiatives. (in Russian)

7. MarcuseH. (2002) Eros i tsivilizatsiya. Odnomernyiy chelovek: issledovanie ideologii razvitogo industrialnogo obschestva [Eros and civilization. Onedimensional person: research of ideology of the developed industrial society]. M.: ACT. (in Russian)

8. Makhni M. (2016)Istoriia psykholohii: navchalnyi posibnyk.[History of Psychology: Textbook]. Kyiv: "Slovo". (in Ukrainian)

9.Borness E. Moore and Bernard D. Fain(ed.)(2000)Psihoanaliticheskie terminyi $i$ ponyatiya: Slovar. [Psychoanalytical terminology and concepts: Dictionary]. M.: "Class". (in Russian)

10. Yatsenko T. S., Bondar V. I., Galushko L. Ya., Kaminska A. M., Pedchenko O. V. (2018) Psykhoanaliz reproduktsii khudozhnikh tvoriv u pidhotovtsi psykholohiv.[Psychoanalysis of artistic works reproductions in the preparation of psychologists:Textbook].Dnipro, Kyiv: Innovatsia. (in Ukrainian) 
11. Yatsenko T. S., Bondar V. I., Evtushenko I. V, Kononova M. M., Maksymenko O. G. (2015) Samodepryvatsiia psykhiky ta dezadaptatsiia subiekta: monohrafiia. [Self-deprivation of psyche and disadaptation of an individual: monograph]. K.: National Pedagogical University namedafter M. Drahomanov. (in Ukrainian)

12. Morozov. S. M., Scaraput L. M. (ed) (2000)Slovnyk inshomovnykh sliv. [Dictionary of foreign words]. K .: Naukova dumka. (in Ukrainian)

13. Frolov I. T (ed) (2001) Filosofskiy slovar. [Philosophical dictionary]. M.: Respublika. (in Russian)

14. Ilyichev L. F., Fedoseev P. N,. Kovalev S. M,. PanovV. G.(ed) (1983)Filosofskiy entsiklopedicheskiy slovar. [Philosophical Encyclopedic Dictionary]. M .: Sov. Encyclopedia. (in Russian)

15. Freud S. (2015) Vstup do psykhoanalizu. [Introduction to Psychoanalysis]. Kharkiv: Knyzhkovyi Klub "Klub Simejnogho Dozvillia”. (in Ukrainian)

16. Freud S. (2017) Maloe sobraniesochineniy. [Collected Works]. St. Petersburg : Azbuka, Azbuka-Atticus. (in Russian)

17. Freud S. (2013) Nedovolstvokulturoy. [Civilization and its Discontents].

Moscow: Folio. (in Russian)

18. Freud S. (2008) Totem i Tabu. [Totem and taboo]. St. Petersburg : Azbukaclassic. (in Russian)

19. Fromm E. (1998) Psihoanaliz i etika.[Psychoanalysis and ethics]. M.: ASTLTD. (in Russian)

20. Hinshelwood R. (2007)Slovar klyaynianskogo psihoanaliza. [Dictionary of Kleinian psychoanalysis]. M.: Kogito Center. (in Russian)

21. Jung C. (2001) Analiticheskayapsihologiya i psihoterapiya. [Analytical Psychology and Psychotherapy]. St. Petersburg: Peter. (in Russian)

22. Yatsenko T.S. (2008) Hlybynna psykholohiia: diahnostyka ta korektsiia tendentsii do psykholohichnoi smerti. [Deep Psychology: Diagnosis and Correction of the Psychological Death Trend] Yalta: KGU. (in Ukrainian) 
23. Yatsenko T. S. (1996) Psykholohichniosnovyhrupovoipsykhokorektsii.

Psychological Basis of Group Psychological Correction]. K.: Lybid. (in Ukrainian)

24. Yatsenko T. (2018) Therelationshipofconsciousandunconscious: psychodynamicapproach. [Psychodynamic look at the relationship between conscious and unconscious]. Fundamentalandappliedresearchesinpractice of leadingscientific schools; 26 (2): 335-353.

25. Yatsenko T. S. (2006) Psykholohichniosnovyhlybynnoipsykhokorektsii, fenomenolohiia, teoriiaipraktyka. [Psychological basics of deep psychological correction, phenomenology, theory and practice]. K .: Vyshcha shkola. (in Ukrainian)

26. Yatsenko T. S., Gluzman A. V (2015) Metodologiya glubinnokorrektsionnoy podgotovki psihologa. [A psychologist's deep correctional trainingmethodology]. Dnepropetrovsk: Innovatsia. (in Russian)

\section{Список використаних джерел}

1. Бибик С. П., Сюта Г. М. Словник іншомовних слів: тлумачення, словотворення та слововживання / За ред. С. Я. Срмоленко; Худож. оформлювач Б. П. Бублик. - Харків : Фоліо, 2006. - 623 с. - (Б-ка держ. Мови).

2. Библия. Книги Священного Писания Ветхого и Нового Завета : «Книжковий Клуб «Клуб Сімейного Дозвілля», 2015 - 1376 с.

3. Войтко В. І. Психологічний словник / під ред. В. І. Войтка. - К. : Видавниче об'єднання «Вища школа», 1982. - 215 с.

4. Головин С. Ю. Словарь практического психолога Текст С. Ю. Головин. Минск: Харвест, 1998. - 800 с.

5. Зеленский В. В. Толковый словарь по аналитической психологии / В. В. Зеленский. - Москва : Когито-Центр, 2008. - 420 с.

6. Лапланш Ж. Словарь по психоанализу / Ж. Лапланш, Ж.-Б. Понталис ; пер. с франц. и науч. ред. Н. С. Автономовой. - 2-е изд., перераб. и доп. - СПб. : Центр гуманитарных инициатив, 2010. - 751 с.

7. Маркузе Г. Эрос и цивилизация. Одномерный человек: исследование идеологии развитого индустриального общества. М. : АСТ, 2002. - 526 с. 
8. Махній М. М. Історія психології: навчальний посібник / М. М. Махній. - Київ: Видавничий Дім “Слово”, 2016. - 472 с.

9. Психоаналитические термины и понятия: Словарь / Под ред. Борнесса Э. Мура и Бернарда Д. Файна / Перев, с англ. А. М. Боковикова, И. Б. Гриншпуна, А. Фильца. - М. : Независимая фирма «Класс», 2000. - 304 с.

10. Психоаналіз репродукцій художніх творів у підготовці психологів: Навчальний посібник / [T. С. Яценко, В. І. Бондар, Л. Я. Галушко, А. М. Камінська, О. В. Педченко]. - Дніпро, Київ : Інновація, 2018. - 300 с.

11. Самодепривація психіки та дезадаптація суб'єкта: монографія / Т. С. Яценко, В. І. Бондар, І. В. Свтушенко, М. М. Кононова, О. Г. Максименко - К. : Вид-во НПУ імені М. Драгоманова, 2015. - 280 с.

12. Словник іншомовних слів / Уклад. : С. М. Морозов, Л. М. Шкарапута. - К. : Наук. думка, 2000. - 680 с. - (Словники України).

13. Философский словарь / Под. Ред. И. Т. Фролова. - 7-е изд., перераб. и доп. - М. : Республика, 2001. - 719 с.

14. Философский энциклопедический словарь / гл. редакция: Л. Ф. Ильичев, П. Н. Федосеев, С. М. Ковалев, В. Г. Панов. - М.: Сов. Энциклопедия, 1983. - 840 с.

15. Фрейд 3. Вступ до психоаналізу / Зигмунд Фрейд ; пер. 3 нім. П. Таращука. - Харків : Книжковий Клуб «Клуб Сімейного Дозвілля», 2015. $480 \mathrm{c}$.

16. Фрейд 3. Малое собрание сочинений / Зигмунд Фрейд ; пер. с. нем. Р. Додельцева, О. Медем, Я. Когана. - СПб. : Азбука, Азбука-Аттикус, 2017. $608 \mathrm{c}$.

17. Фрейд 3. Недовольство культурой / Зигмунд Фрейд; пер. с нем. А. Руткевича. - Фолио : Москва, 2013. - 256 с.

18. Фрейд 3. Тотем и табу / 3. Фрейд. пер. с нем. М. В. Вульфа. - СПб. : Издательский дом Азбука-классика, 2008. - 256 с.

19. Фромм Э. Психоанализ и этика. - М. : ООО «Издательство АСТЛТД», 1998. - 568 с. (Классика зарубежной психологии). 
20. Хиншелвуд Р. Словарь кляйнианского психоанализа / Пер. с англ. М. : Когито-Центр, 2007. - 566 с. (Библиотека психоанализа).

21. Юнг К. Аналитическая психология и психотерапия: Хрестоматия / Сост. В. М. Лейбин. - СПб.: Питер, 2001. - 512 с. : ил. - (Серия «Хрестоматия»).

22. Яценко Т. С. Глибинна психологія: діагностика та корекція тенденції до психологічної смерті / Т. С. Яценко, О. В. Глузман, І. В. Калашник. - Ялта : РВВ КГУ, 2008. - 204 с.

23. Яценко Т. С. Психологічні основи групової психокорекції [Текст] : навч. посібник / Т. С. Яценко. - К. : Либідь, 1996. - 264 с.

24. Яценко T. The relationship of conscious and unconscious: psychodynamic approach. [Психодинамічний погляд на взаємозв'язки свідомого і несвідомого]. Fundamental and applied researches in practice of leading scientific schools. -2018. - № 26 (2). - C. 335-353.

25. Яценко Т. С. Психологічні основи глибинної психокорекції, феноменологія, теорія і практика / Т. С. Яценко. - К.: Вища шк., $-2006-382$ с.

26. Яценко Т. С., Глузман А. В. Методология глубинно-коррекционной подготовки психолога / Т. С. Яценко, А. В. Глузман. - Днепропетровск : Инновация, 2015. - 394 с. 